\title{
MANAJEMEN PEMBINAAN KOMPETENSI GURU MADRASAH ALIYAH BERBASIS PESANTREN
}

\author{
Wahyu Hidayat \\ Fakultas Pendidikan Islam dan Keguruan (FPIK) Universitas Garut \\ Jl. Cimanuk No. 285 A Tarogong Garut 44151 \\ E-mail:wahyu1974@yahoo.com
}

\section{ABSTRAK}

Penelitian ini bertujuan mengetahui dan menganalisis perencanaan, pengorganisasian, pelaksanaan dan evaluasi pembinaan kompetensi guru madrasah aliyah (MA) berbasis pesantren. Lokasi penelitian dilaksanakan di MA Darul Arqam Muhamadiyah Garut dan MAN Cipasung Tasikmalaya. Penelitian ini menggunakan pendekatan kualitatif. Data dikumpulkan melalui observasi, wawancara dan studi dokumentasi. Kualifikasi akademik guru pada kedua madrasah umumnya telah memenuhi kualifikasi pendidikan minimal sebagaimana diamanatkan oleh Undang-Undang Guru dan Dosen No. 14 Tahun 2005. Perencanaan pembinaan kompetensi guru pada kedua madrasah umumnya menggunakan 3 tahap yaitu; diagnosis, perencanaan dan penyusunan dokumen. Wewenang pembinaan berada pada kepala madrasah dan pimpinan pesantren. Pelaksanaan pembinaan dilakukan melalui program peningkatan kualifikasi akademik, sertifikasi, pelatihan terintegrasi dan supervisi. Dasar kegiatan pembinaan senantiasa mengacu pada Sunnah Rasulullah SAW dan tradisi para alsalaf as-shâlih. Evaluasi pembinaan dilakukan terhadap aspek kompetensi guru. Hasil evaluasi ditindaklanjuti dalam bentuk workshop, perbaikan dan pencegahan.

Kata Kunci: Manajemen Pembinaan, Kompetensi Guru, Madrasah, Pesantren

\section{ABSTRACT}

This study is proposed to identify and analyse the development of planning, organization, implementation and evaluation of teacher competence Pesantren-based Madrasah Aliyah. The research site was Darul Arqam MA Mubammadiyah MAN Cipasung Garut and Tasikmalaya. This study utilized a qualitative approach. Data were collected through observations, interviews and documentation. Academic qualifications of teachers in the two madrasas generally have met the minimum educational qualification as mandated by Law number 14 of 2005 regarding Teachers and Lecturers. Planning for teacher competency training in both madrasah generally use 3 stages, namely: diagnosis, planning and preparation of documents. The authority to conduct the training is in the head of madrasah or the leader of pesantren. The implementation of the trainings done through the program for improving the academic qualification, certification, integrated training and supervision. Basic principles of this trating activity always refers to the Sunnah of the Prophet Muhammad and the tradition of the al-salaf as-shâlih. Evaluation was conducted conducted on aspects of teacher competence. The evaluation results were followed up by workshop, remedial and preventive programs in the form of workshops, repair and prevention.

Keywords: Management Coaching, Teacher Competency, Madrasa, Pesantren 


\section{PENDAHULUAN}

Guru merupakan komponen paling menentukan dalam proses pembelajaran karena di tangan guru, kurikulum, sarana dan prasarana serta iklim pembelajaran menjadi suatu yang berarti bagi kehidupan peserta didik (Mulyasa, 2007b: 5). Menurut Darling-Hamond (2006:10) guru harus bisa menjadi pendiagnosis, organisator pengetahuan dan pelatih terampil untuk membantu para siswa menguasai informasi dan sejumlah keterampilan yang sangat kompleks. Guru berperan dalam pembentukan karakter dan sikap murid karena murid kecuali membutuhkan pengetahuan tentang nilai baik-buruk, benar-salah, dan indah-tidak indah juga membutuhkan contoh dari gurunya. Oleh karena itu dibutuhkan guru yang bermutu karena perannya dalam pengembangan intelektual, emosional dan spiritual murid sangat penting. Kualitas guru merupakan komponen utama bagi suksesnya penyelenggaraan pendidikan (Darling-Hamond, 2006: 5).

Menurut Killen (1998: v) pengetahuan, kemampuan dan keyakinan guru berpengaruh secara langsung terhadap hal-hal yang dipelajari oleh siswa. Oleh sebab itu kompetensi guru dalam proses pendidikan merupakan tuntutan yang tidak dapat ditawar-tawar lagi agar ia bisa menjalankan tugasnya secara ideal. Menurut Surya sebagaimana yang dikutip oleh Hadiyanto (2004: 12) bahwa guru yang ideal memiliki sembilan karakteristik, yaitu: (1) memiliki semangat juang yang tinggi disertai kualitas keimanan dan ketakwaan yang mantap; (2) mampu mewujudkan dirinya dalam keterkaitan dan padanan dengan tuntutan lingkungan dan perkembangan ilmu pengetahuan dan teknologi; (3) mampu belajar dan bekerja sama dengan orang yang memiliki profesi lain; (4) memiliki etos kerja yang kuat; (5) memiliki kejelasan dan kepastian pengembangan jenjang karir; (6) berjiwa profesional tinggi; (7) sejahtera lahir dan batin, material dan non material; (8) memiliki wawasan masa depan yang baik; (9) mampu melaksanakan fungsi dan peranannya secara profesional.

Masalah umum yang dihadapi oleh madrasah adalah kurangnya peminat/calon siswa, terbatasnya dukungan dana dan masih rendahnya kualitas guru. Rendahnya kualitas guru ditandai dengan masih rendahnya semangat kerja, kreatifitas, inovasi dan kualitas layanan keguruan. Undang-Undang Nomor 20 tahun 2003 tentang Sistem Pendidikan Nasional telah mengamanatkan bahwa keberadaan madrasah sudah setara dengan sekolah umum lainnya bahkan madrasah diposisikan sebagai sekolah yang berciri khas Islam sesuai dengan tingkatannya. Ini bermakna bahwa payung hukum institusi madrasah sudah jelas dan tidak ada dikotomi lagi antara sekolah yang dikelola oleh Kementerian Pendidikan dan Kebudayaan dengan madrasah yang dikelola oleh Kementerian Agama. Dengan demikian, madrasah merupakan bagian yang tak terpisahkan dari sistem pendidikan nasional. Hal itu sejalan dengan pendidikan nasional bahwa madrasah mempunyai fungsi yang sama dengan satuan pendidikan lainnya terutama dalam mengembangkan kemampuan dan membentuk watak serta peradaban bangsa dan bertujuan untuk mengembangkan potensi peserta 
didik agar menjadi manusia yang beriman dan bertakwa kepada Tuhan Yang Maha Esa, berakhlak mulia, sehat, berilmu, cakap, kreatif, mandiri dan menjadi warga negara yang demokratis serta bertanggung jawab. Namun kenyataannya madrasah seringkali diposisikan sebagai sekolah kelas dua (second class) ketika dibandingkan dengan sekolah umum. Kalaupun ada madrasah yang bisa bersaing dengan sekolah setingkatnya, itu sifatnya hanya kasuistis saja, misalnya Madrasah Aliyah Insan Cendekia di Serpong Tanggerang yang dianggap telah maju dan berkualitas. Azizi dalam harian kompas (02/02/06) menyatakan bahwa madrasah selama ini dihadapkan pada beberapa masalah, bukan hanya soal minimnya dana operasional tetapi juga keterbatasan tenaga guru, ketidakjelasan status guru, ketidaklayakan kualifikasi guru, ketidaklayakan ruang kelas dan tidak proporsionalnya pembiayaan siswa (http://www.kompas.com/29/01/11).

Label bahwa madrasah adalah sekolah kelas ke dua (second class) cukup berpengaruh terhadap rendahnya animo masyarakat kelas menengah ke atas untuk melanjutkan pendidikan putra-putrinya ke madrasah. Bahkan banyak di antara mereka yang memasukkan putra putrinya ke madrasah didasari oleh keterpaksaan karena tidak diterima di sekolah umum. Ada beberapa orang tua yang memasukkan sekolah ke madrasah karena ia sudah kewalahan mendidik akhlak anaknya. Artinya anak tersebut nakal dan biasanya sekolah lain tidak ada yang mau menerimanya. Kondisi ini mengakibatkan in put siswa yang masuk ke madrasah umumnya kecuali memiliki tingkat kecerdasan yang tidak begitu baik juga berakhlak kurang baik. Persoalan lain adalah kualitas guru. Ketidakjelasan status dan ketidaklayakan kualifikasi akademiknya menyebabkan ada kecenderungan bahwa siapa pun boleh menjadi guru madrasah tanpa melihat latar belakang pendidikannya.

Menurut Firdaus, Direktur Mapenda Kementerian Agama RI, kelemahan yang dihadapi oleh madrasah selama ini adalah persoalan kualitas guru. Guru merupakan faktor dominan yang dapat memengaruhi kualitas lulusan madrasah. Ia pun menjelaskan bahwa 63\% kualitas lulusan madrasah dipengaruhi oleh kualitas guru, bukan manajemen atau fasilitas yang berlimpah. Saat ini, 54\% dari 628 ribu guru madrasah belum memenuhi kualifikasi minimal pendidikan S-1 atau D-4 yang sesuai antara kualifikasi akademik dengan mata pelajaran yang diaampu (http://batakpos-online.com/content/view/5677/60/ diunduh Senin 23/3/11 dan 09/08/11).

Di kabupaten Garut, masih banyak guru madrasah yang belum memenuhi kualifikasi minimal S1 dan D4 (http://mapenda-garut. blogspot.com /2012/07/bantuan-peningkatan-kualifikasi program.html). Di Tasikmalaya juga masih banyak guru madrasah yang belum memenuhi kualifikasi akademik seperti yang dikehendaki dalam Undang Undang Guru dan Dosen Nomor 14 tahun 2005 yang mensyaratkan kualifikasi akademik minimal S1 atau D4 (http://mapendakbtasikmalaya.blogspot.com/2012/07). Dengan demikian, usaha pembinaan guru menjadi urgent karena guru madrasah banyak yang masih berstatus sebagai guru tidak tetap dan honorer. Latar belakang pendidikan 
mereka pun sangat bervariasi sehingga berpengaruh terhadap kompetensi dirinya sebagai guru madrasah. Pembinaan kompetensi guru khususnya pada madrasah yang berbasis pesantren perlu dilakukan dengan menggunakan pendekatan manajemen modern agar mereka tetap eksis bahkan bisa diandalkan dalam mengatasi persoalan pengelolaan pendidikan Islam di Indonesia.

Fokus masalah penelitian ini adalah bidang manajemen personil yaitu tenaga guru. Ada dua madrasah aliyah yang berbasis pesantren yang dijadikan sebagai subjek penelitian, yaitu Madrasah Aliyah (MA) Darul Arqam Garut dan Madrasah Aliyah Negeri (MAN) Cipasung Tasikmalaya. Aspek yang diteliti adalah kualifikasi akademik dan kompetensinya yang meliputi perencanaan, pengorganisasian, pelaksanaan dan evaluasi hasil pembinaan kompetensi guru serta konsep/strategi baru yang diajukan dalam pembinaan kompetensi guru Madrasah Aliyah (MA) Darul Arqam Garut dan Madrasah Aliyah Negeri (MAN) Cipasung Tasikmalaya yang melingkupi empat hal, yakni: 1) Peningkatan kualifikasi akademik; 2) Program sertifikasi; 3) Program pelatihan terintegrasi; dan 4) Supervisi. Adapun pembinaan yang dimaksud adalah: 1) Pembinaan yang dapat mengembangkan kompetensi guru dalam menjalankan tugasnya dengan baik yang didukung oleh kualifikasi pendidikan minimal sebagai guru yaitu berijazah S1 atau D4 ditambah dengan sertifikat pendidik; 2) Berusaha meningkatkan kompetensi pedagogik, kepribadian, sosial dan profesional guru madrasah dengan mengadakan berbagai kegiatan yang dapat menunjang profesionalisme guru seperti supervisi, program sertifikasi, pelatihan, seminar, workshop, up-grading dan forum diskusi. Penelitian ini bertujuan menggambarkan kompetensi profesional guru madrasah Aliyah yang berbasis pesantren baik mengenai kualifikasi akademik maupun kompetensinya juga menjelaskan dan menganalisis manajemen pembinaan kompetensi guru yang dilaksanakan dan dikembangkan oleh pengelola madrasah.

Madrasah Aliyah Darul Arqam Garut dan MAN Cipasung Tasikmalaya merupakan representasi institusi pendidikan Islam yang dikembangkan oleh dua ormas Islam yang berbeda, yakni Muhammadiyah dan Nahdlatul Ulama (NU). Dengan demikian keduanya memiliki tradisi yang berbeda namun secara umum pengelolaannya sudah menggunakan manajemen modern. Tradisi kepesantrenan kedua lembaga tersebut sedemikian rupa telah dipadukan dengan pengelolaan madrasah modern yang tercermin pada penyelenggaraan sekolah/madrasah oleh kedua pesantren tersebut. Metode penelitian ini bersifat deskriptif dari subjektif ke objektif dan dari induktif ke deduktif (Lecomte \& Goetz, 1984: 4-7) dengan pendekatan kualitatif yang menurut Lincoln dan Guba (1985: 39) disebut sebagai "Naturalistik Inquiry". Artinya, pengamatan dan pengumpulan data dilakukan dalam latar/setting alamiah, tanpa manipulasi subyek yang diteliti maupun dari peneliti, sistematis dan faktual. Hal ini sesuai dengan pendapat Bugin (2007: 68) bahwa metode deskriptif bertujuan untuk menggambarkan, meringkas berbagai kondisi, situasi atau fenomena/realitas sosial yang ada di masyarakat yang menjadi objek penilaian dan berupaya menarik realitas itu ke permukaan sebagai 
suatu ciri, karakter, sifat, model, tanda atau gambaran tentang kondisi, situasi atau fenomena tertentu.

Teknik pengumpulan data yang digunakan dalam penelitian ini adalah wawancara, observasi dan studi dokumentasi. Sumber data meliputi manusia/orang dan bukan manusia. Sumber data manusia berfungsi sebagai subjek atau informan kunci (key informan). Sumber data yang bukan manusia meliputi dokumen yang relevan dengan fokus penelitian, seperti gambar, foto, catatan tentang rapat, dan tulisan-tulisan yang ada kaitannya dengan fokus penelitian. Penentuan informan dalam penelitian ini didasarkan pada kriteria: 1) subjek cukup lama dan intensif menyatu dengan medan aktivitas yang menjadi sasaran penelitian, 2) subjek yang masih aktif terlibat dalam lingkungan aktivitas yang menjadi sasaran penelitian, 3) subjek mempunyai waktu untuk diminati informasi oleh peneliti, 4) subjek tidak mengemas informasi, tetapi relatif memberikan informasi yang sebenarnya, dan 5) subjek yang tergolong asing bagi peneliti. Pemilihan informan dilakukan secara purposif (purposive sampling). Ini memberi kebebasan peneliti dari keterikatan proses formal dalam mengambil sampel, yang berarti dapat menentukan sampling sesuai dengan tujuan penelitian dan didasarkan pada relevansi dari kealamiahan informasi dan tema yang muncul di lapangan. Dengan teknik purposif ini, ditetapkan sampel yang menjadi informan kunci yaitu; 1) Pengawas (2) Kepala Madrasah dan wakil kepala madrasah, 3) Pimpinan pesantren (Kiai), dan 4) Guru. Teknik sampling bola salju (snow ball) digunakan untuk mencari informasi secara terus-menerus dari informan satu ke informan lainnya, sehingga data yang diperoleh semakin banyak, lengkap dan mendalam. Teknik bola salju selain untuk memilih informan yang dianggap paling mengetahui masalah yang dikaji, juga cara memilihnya dikembangkan sesuai kebutuhan dan kemantapan peneliti dalam mengumpulkan data. Proses analisis data yang diperoleh dari lapangan dilakukan melalui model analisis data interaktif (interactive model). Sejumlah langkah analisis terdapat dalam model ini, yakni reduksi data, penyajian data dan penarikan kesimpulan mengacu pada Miles dan Huberman (1992: 15-20). Untuk menguji keabsahan data yang dikumpulkan, peneliti menggunakan teknik pemeriksaan yang didasarkan pada empat kriteria, yaitu: derajat kredibilitas, transferabilitas, dependabilitas dan konfirmabilitas.

\section{PEMBAHASAN}

Al-Qur'an surat an-Nahl [16] ayat 125 menyatakan; "Serulah (manusia) kepada jalan Tuhan-mu dengan hikmah dan pelajaran yang baik dan bantablab mereka dengan cara yang baik. Sesunggubnya Tubanmu dialah yang lebih mengetabui tentang siapa yang tersesat dari jalan-Nya dan dialah yang lebih mengetabui orang-orang yang mendapat petunjuk" dan hadis Nabi:

$$
\text { إذا وسد الأمر إلى غير أهله فانتظر الساعة }
$$


"Iika sebuah urusan diserabkan kepada orang yang bukan ablinya, maka tunggulah kehancurannya." (HR. Bukhari). Hal ini berarti bahwa dalam pendidikan itu diperlukan metode pembelajaran yang baik dan orang yang menggunakannya harus ahli, yakni guru-guru yang profesional serta memiliki kualifikasi/kompetensi yang tinggi.

Von Glaserfeld mengatakan bahwa pengetahuan adalah hasil dari konstruksi (bentukan) manusia itu sendiri. Manusia mengonstruksi pengetahuan mereka melalui interaksi mereka dengan objek, fenomena, pengalaman dan lingkungan mereka. Suatu pengetahuan dianggap benar bila pengetahuan itu dapat berguna untuk menghadapi dan memecahkan persoalan yang sesuai dengan kebutuhan (Suparno, 1997: 27-28). Dengan demikian, guru hendaknya memiliki kemampuan untuk senantiasa memecahkan persoalan yang berhubungan dengan ketidaklancaran dalam pelaksanaan pembelajaran, melalui cara-cara yang profesional dan baik sehingga guru benar-benar terberdayakan.

Clutterbuck (1999: 182) mengatakan bahwa pemberdayaan itu intinya memberikan daya agar seseorang dapat mengatasi masalah yang dihadapinya. Orang akan dipandang berdaya ketika ia mampu menunjukan beberapa perilaku, di antaranya; 1) Develop the skill needed to take responsibility; 2) Develop effective networks of information and influence; 3) Enhance personal and team creativity; 4) Maintain a health; 5) Balance between work and personal life; and 6) Keep learning. Berarti, seseorang dianggap berdaya apabila orang tersebut dapat mengembangkan kemampuan yang diperlukan untuk memikul tanggungjawab yang diberikan kepadanya. Dia juga harus mampu mengembangkan jaringan informasi yang efektif dan berpengaruh, meningkatkan kreativitas diri dan kelompok/tim/organisasinya, menjaga kesehatan fisik dan mental, seimbang antara kerja dan kehidupan pribadi serta melakukan belajar secara berkelanjutan (life long education).

Menurut Spencer and Spencer, kompetensi seseorang dapat digambarkan sebagai karakteristik dasar individu yang menggunakan bagian kepribadiannya sehingga dapat mempengaruhi perilakunya ketika orang yang bersangkutan menghadapi suatu tugas atau pekerjaan tertentu. Kompetensi merangkum lima hal, yaitu: motivasi (motives), kemampuan merespons (traits), memiliki konsep diri (self concept), berpengetahuan (knowledge) dan berkeahlian (skill) (Spencer, 1993: 911).

George Terry (1977) berpendapat bahwa fungsi manajemen ada empat yakni: planning (perencanaan), organizing (pengorganisasian), actuating (pelaksanaan) dan controlling (pengawasan). Planning (perencanaan) merupakan pekerjaan mental untuk memilih sasaran, kebijaksanaan, prosedur, program yang diperlukan untuk mencapai apa yang diinginkan pada masa yang akan datang. Organizing (pengorganisasian) menggambarkan hubungan antar manusia sebagai akibat organisasi serta menunjukkan hubungan antar unit-unit atau departemendepartemen kerja. Pengorganisasian ini menuntut penetapan pembagian kerja, pembatasan tugas dan tanggung jawab serta wewenang. Actuating (pelaksanaan) merupakan implementasi dari perencanaan dan pengorganisasian sementara 
controlling (pengawasan) merupakan pengawasan secara menyeluruh terhadap keseluruhan proses dari mulai perencanaan, pengorganisasian dan pelaksanaan.

\section{Kualifikasi Akademik Guru Madrasah Berbasis Pesantren}

Kualifikasi akademik guru-guru Madrasah Aliyah Darul Arqam Muhammadiyah Garut sudah seratus persen S1 bahkan ada lima guru yang berkualifikasi S2. Madrasah ini dibina oleh guru secara bersama-sama di bawah naungan Pesantren Darul Arqam. Pada Madrasah Aliyah Negeri Cipasung Tasikmalaya ternyata sudah seratus persen S1 bahkan ada empat belas orang guru yang berkualifikasi S2. Berarti, kompetensi guru seperti yang diamanatkan dalam Permendiknas nomor 16 tahun 2007 bahwa harus memiliki kualifikasi akademik minimal S1 atau D4 telah dipenuhi oleh kedua madrasah berbasis pesantren ini namun demikian kesesuaian antara latar belakang pendidikan guru dengan mata pelajaran yang diampu masih belum sepenuhnya terpenuhi.

Menurut pimpinan Pesantren Darul Arqam: ...."pesantren kami dibina oleh guru-guru yang memiliki latar belakang pendidikan sesuai dengan bidang keablian dan latar belakang pendidikan yang dimilikinya" (DA/A.1.2011). Dalam hal ini, kepala MAN Cipasung menjelaskan bahwa:... Untuk tenaga pendidikan alhamdulillah, mereka yang mengajar secara umumnya di sini telab sesuai dengan latar belakang pendidikan yang dimilikinya hanya guru olah raga yang tidak sesuai... (MC/B.3.2011). Berdasarkan hasil wawancara, observasi dan studi dokumentasi ternyata seluruh guru di Madrasah Aliyah Darul Arqam Muhammadiyah Garut berijazah sesuai dengan mata pelajaran yang diampunya sedangkan pada Madrasah Aliyah Negeri Cipasung sekitar 99\% telah memenuhi linieritas antara mata pelajaran yang diajarkan dengan latar belakang pendidikan yang dimilikinya. Berarti, guru pada Madrasah Aliyah Darul Arqam Muhammadiyah Garut telah memenuhi syarat minimal seperti yang dikehendaki dalam Undang-Undang Guru dan Dosen No. 14 tahun 2005 yakni minimal S1 atau D4 bahkan madrasah tersebut terus mengupayakan agar guru dapat meningkatkan kualifikasi akademik dengan cara studi lanjut ke jenjang S2. Ada beberapa guru yang sedang studi S2 bahkan ada yang sudah menyandang gelar S2 (DA/A.3.2011 dan MC/A.3.2011).

\section{Manajemen Pembinaan Kompetensi Guru Madrasah Berbasis Pesantren}

Proses perencanaan pembinaan kompetensi guru yang dilakukan oleh pimpinan Pesantren Darul Arqam Muhammadiyah Garut dan Madrasah Aliyah Negeri Cipasung Tasikmalaya dimulai dari merumuskan visi, misi, tujuan, sasaran, strategi dan kebijakan. Proses perencanaan ini melalui tiga tahapan yang meliputi; (1) diagnosis, (2) perencanaan, dan (3) penyusunan dokumen rencana program pembinaan kompetensi guru. Sumber informasi dalam perencanaan pembinaan kompetensi guru mengacu pada rumusan visi, misi, tujuan dan kebijakan Pondok Pesantren Darul Arqam Muhammadiyah Garut yang telah ditetapkan (DA/A.1.2011). Dalam membuat perencanaan serta pengorganisasian tentang pembinaan kompetensi guru melibatkan banyak pihak seperti kepala madrasah, wakil kepala madrasah (wakamad) bagian akademik dan kurikulum, 
wakamad bagian administrasi dan keuangan, guru senior bahkan melibatkan komite madrasah (DA/A.3.2011 dan MC/B.3.2011). Semua pihak yang terlibat melakukan rempug bersama guna menghasilkan dekumen perencanaan pembinaan kompetensi guru baik di Madrasah Aliyah Darul Arqam maupun pada Madrasah Aliyah Negeri Cipasung. Dokumen tersebut memuat rumusan tujuan, masalah, hambatan, alternatif tindakan dan penetapan kriteria keberhasilannya.

Dokumen perencanaan yang telah dibuat selanjutnya dijadikan bahan pijakan dalam pelaksanaan pembinaan kompetensi guru Madrasah Aliyah Darul Arqam Muhammadiyah Garut dan Madrasah Aliyah Negeri Cipasung Tasikmalaya yang terfokus pada: 1) Pembinaan yang dapat mengembangkan kompetensi guru dalam menjalankan tugasnya dengan baik yang didukung oleh kualifikasi pendidikan minimal sebagai guru. Kualifikasi pendidikan minimal yang dikehendaki undang-undang sebagai prasyarat kelayakan bagi seorang guru adalah memiliki ijazah S1 atau D4 ditambah dengan sertifikat pendidik; 2) Berusaha meningkatkan kompetensi pedagogik, kepribadian, sosial dan profesional guru madrasah dengan mengadakan berbagai kegiatan yang dapat menunjang profesionalisme guru seperti: supervisi, program sertifikasi, pelatihan, seminar, workshop, up-grading, dan forum diskusi.

Strategi pembinaan kompetensi guru pada Madrasah Aliyah Darul Arqam Garut dan Madrasah Aliyah Negeri Cipasung Tasikmalaya difokuskan dalam empat hal, yakni: 1) Peningkatan kualifikasi akademik, 2) Program Sertifikasi, 3) Program pelatihan terintegrasi, dan 4) Supervisi. Dalam pelaksanaan pembinaannya, kedua madrasah yang berbasis pesantren ini mendasarkan diri pada Sunah Rasulullah SAW dan tradisi para al-salaf as-shâlih dalam membina umatnya. Sunah dan tradisi para al-salaf as-shâlih itu berdasarkan pada pesan Ilâhiyyah sebagaimana yang tercantum dalam Kitâbullâh, yakni: lillâh, uswatun hasanah, bil-hikmah, mauidzah hasanah dan mujâdalah.

Pola Pendidikan yang dikembangkan oleh Madrasah Aliyah Darul Arqam Muhammadiyah Garut dan Madrasah Aliyah Negeri Cipasung Tasikmalaya dilakukan secara terpadu antara lembaga formal (madrasah) dengan lembaga non formal (pesantren). Dengan menggunakan model ini, pembinaan terhadap siswa dilakukan secara integral dan terpadu antara kurikulum nasional dengan kurikulum kepesantrenan. Secara teoretis, model pendidikan jenis madrasah yang berbasis pesantren ini dapat melahirkan kualitas lulusan yang tidak saja unggul secara akademik tetapi juga dapat membentuk character building, personality development dan lifeskill.

Dalam evaluasi kegiatan pembinaan kompetensi guru pada Madrasah Aliyah Darul Arqam Garut dan Madrasah Aliyah Negeri Cipasung Tasikmalaya melibatkan pimpinan pesantren, pengawas dan kepala madrasah (DA/MC.A.B.3.2011). Sesuai dengan tradisi di pesantren, peran kiai sebagai pimpinan pesantren sangat dominan, sehingga kegiatan evaluasi dalam 
pembinaan guru juga melibatkan kiai. Inilah yang menjadi ciri khas pesantren bila dibandingkan dengan institusi pendidikan lainnya.

MA Darul Arqam Muhammadiyah Garut dan MAN Cipasung Tasikmalaya telah menyusun program pengawasan berdasarkan pada Standar Nasional Pendidikan yang telah ditetapkan. Program pengawasan tersebut disosialisasikan kepada tenaga pendidik dan kependidikan. Pengawasan pengelolaan madrasah meliputi pemantauan, supervisi, evaluasi, pelaporan dan tindak lanjut hasil pengawasan. Pemantauan pengelolaan madrasah dilakukan oleh majelis madrasah atau bentuk lain dari lembaga perwakilan pihak-pihak yang berkepentingan secara teratur dan berkelanjutan untuk menilai efesiensi, efektivitas dan akuntabilitas pengelolaan madrasah. Supervisi pengelolaan akademik dilakukan secara teratur dan berkelanjutan oleh kepala madrasah dan pengawas, termasuk oleh pimpinan pesantren. Sedangkan guru melaporkan hasil evaluasi dan penilaian setiap akhir semester yang ditujukan kepada kepala madrasah dan orang tua/wali peserta didik (DA/MC/AB/3.2011).

Madrasah Aliyah Darul Arqam Muhammadiyah Garut melakukan beberapa langkah dalam melakukan pembinaan terhadap kompetensi guru, di antaranya: 1) Rekrutmen guru berdasarkan kebutuhan dan memenuhi kualifikasi akademik minimal S1 dan mempunyai latar belakang pendidikan yang bersesuaian dengan mata pelajaran yang diampunya; 2) Penilaian kinerja dan kompetensi guru oleh pengawas, kepala madrasah, wakil kepala madrasah dan guru senior (DA/A.3.2011). Madrasah Aliyah Negeri Cipasung Tasikmalaya juga melakukan langkah-langkah pembinaan kompetensi guru yaitu: 1) Rekrutmen untuk tenaga guru yang dilakukan pada Madrasah Aliyah Negeri Cipasung Tasikmalaya ditentukan oleh mekanisme yang diatur sepenuhnya oleh kantor kementerian Agama. Materi tes meliputi tes kompetensi, psikotes dan tes pemahaman keagamaan. Guru yang bisa mengikuti tes ini disesuaikan dengan formasi yag telah ditetapkan oleh pemerintah sesuai dengan formasi kebutuhan yang sesuai dengan latar belakang pendidikan yang dimiliki; 2) Pengoreksian silabus dan Rencana Pelaksanaan Pembelajaran (RPP) dilakukan oleh kepala madrasah dan pengawas; dan 3) Penilaian kinerja oleh kepala madrasah, pengawas dan pimpinan pesantren dilakukan secara berkala terutama berkenaan dengan loyalitas dan komitmen guru dalam melaksanakan tugasnya (MC/B.3.2011).

Tindak lanjut terhadap hasil evaluasi pembinaan kompetensi guru berupa rekomendasi atas hasil kegiatan evaluasi pembinaan kompetensi guru. Perumusan tindak lanjut hasil evaluasi pada Madrasah Aliyah Darul Arqam Muhammadiyah Garut dan Madrasah Aliyah Negeri Cipasung Tasikmalaya dilaksanakan secara berjenjang. Biasanya dilakukan di akhir semester menjelang liburan atau kadang dilakukan pada saat persekolahan akan dimulai yakni pasca liburan semester. Ada dua langkah yang dilakukan dalam rangka menindaklanjuti hasil evaluasi pembinaan kompetensi guru, yakni workshop dan tindakan perbaikan dan/atau pencegahan. Workshop pembinaan kompetensi guru 
merupakan wahana dalam meningkatkan kompetensi guru sekaligus sebagai media membuat laporan kegiatan pembinaan kompetensi guru dengan memberikan rekomendasi kepada pengelola madrasah. Workhshop pembinaan kompetensi guru di Madrasah Aliyah Darul Arqam Muhammadiyah Garut dan Madrasah Aliyah Negeri Cipasung Tasikmalaya berhubungan baik dengan penyusunan program pembelajaran semesteran dan tahunan maupun dengan workshop kurikulum dan silabus hingga pada tingkat penyusunan Rencana Pelaksanaan Pembelajaran (RPP). Workshop pembinaan kompetensi guru juga dijadikan sebagai wahana dalam membangun kembali motivasi guru dalam pelaksanaan pembelajaran. Dalam workshop ini, nilai-nilai religius menjadi materi utama dengan mengedepankan prinsip-prinsip sebagai berikut: lillâh, uswatun hasanah, mavizhah hasanah dan mujâdalah.

Perbaikan hasil evaluasi dan pencegahan terhadap kemungkinan terulangnya kembali kesalahan yang sama dilakukan oleh Pengelola Madrasah Aliyah Darul Arqam dan Madrasah Aliyah Negeri Cipasung dengan menetapkan prosedur tindakan perbaikan dan pencegahan. Tindakan perbaikan dilakukan untuk menghilangkan penyebab ketidaksesuaian sehingga mencegah terulangnya kembali kejadian yang sama, sedangkan tindakan pencegahan dilakukan untuk mengatasi penyebab potensial ketidaksesuaian langkah dan cara pembinaan kompetensi guru sehingga dapat dicegah. Hasil tindakan perbaikan dan pencegahan tidak menutup kemungkinan dapat mengubah dan memperbaiki prosedur dan dokumen pembinaan kompetensi guru.

\section{Analisis SWOT Terhadap Manajemen Pembinaan Kompetensi Guru Madrasah Berbasis Pesantren}

1. Madrasah Aliyah Darul Arqam Garut

Madrasah Aliyah Darul Arqam Garut sebagai lembaga pendidikan yang telah berdiri secara sah dan menjadi bagian yang tak terpisahkan dari sistem pendidikan nasional memiliki beberapa kekuatan. Kekuatan tersebut adalah tenaga pendidik yang sudah memenuhi kualifikasi minimal seperti yang diamanatkan dalam Permendiknas Nomor 16 tahun 2007 (S1 dan atau D IV), tenaga kependidikan serta sarana dan prasarana yang memadai, madrasah yang telah terakreditasi dan sudah terlibat serta dilibatkan dalam berbagai kegiatan pendidikan, baik skala lokal, regional ataupun nasional yang diselenggarakan oleh pemerintah atau organisasi pendidikan lainnya.

Dalam menyelenggarakan pendidikan, Madrasah Aliyah Darul Arqam Garut sebagai lembaga pendidikan kader (Muhamadiyah) memadukan secara seimbang antara mata pelajaran umum dengan mata pelajaran kepesantrenan. Dengan demikian, lulusan madrasah ini dapat melanjutkan pendidikannya ke perguruan tinggi umum yang berada di bawah naungan Kementerian Pendidikan dan Kebudayaan maupun ke perguruan tinggi agama yang berada di bawah naungan Kementerian Agama Republik Indonesia. Bahkan lulusannya dapat 
melanjutkan kuliah ke perguruan tinggi luar negeri, seperti Mesir, Saudi Arabia, Libya dan Amerika Serikat.

Kekuatan dari sisi tenaga kependidikan yang telah seratus persen memiliki kualifikasi pendidikan S1, lebih memudahkan madrasah ini untuk melakukan pembinaan yang dilakukan oleh pengawas, kepala madrasah dan pimpinan pesantren. Hal ini sesuai dengan yang dikehendaki oleh Undang-Undang Guru dan Dosen No. 14 tahun 2005 khususnya pasal 8 dan 9 yang mensyaratkan pendidikan S1 atau D IV.

Pola rekrutmen guru diselenggarakan oleh lembaga tanpa melibatkan pihak ketiga. Hal ini memberi ruang kurang baik dalam objektivitas penerimaan. Di samping itu, kesejahteraan pendidik sering kali menjadi isu yang perlu mendapat perhatian khusus. Hal ini terjadi karena seringkali guru yang berkualitas dan telah mengabdi di Darul Arqam Garut ketika mendapat kesempatan untuk menjadi Pegawai Negeri Sipil (PNS), mereka tidak serta-merta ditempatkan di tempat asal mereka mengabdi. Hal ini terjadi karena terbatasnya jumlah yang diangkat sebagai Pegawai Negeri Sipil (PNS) dan kemudian mereka ditempatkan di sekolah lain karena alasan pemerataan tenaga pendidik. Oleh sebab itu, dukungan secara finansial merupakan hal yang penting, agar para guru dapat mengabdi dengan sepenuh hati di madrasah ini tanpa harus mencari pekerjaan sambilan di luar tugas pokoknya sebagai pendidik. Jabatan guru merupakan jabatan terhormat, dengan demikian perlu didukung oleh kesejahteraan yang memadai agar guru dapat melaksanakan tugasnya dengan sepenuh hati. Hal ini sejalan dengan amanat Undang-Undang Guru dan Dosen No. 14 tahun 2005, khususnya pasal 14, 15, 16, 17, 18 dan 19.

Dari segi infrastuktur, keterbatasan ruang kelas dan sarana lainnya berdampak terhadap daya tampung siswa, sehingga pihak sekolah belum dapat memenuhi warga Muhammadiyah dan masyarakat Islam pada umumnya agar putra dan putrinya dididik di madrasah ini, manakala keadaan asrama masih kurang baik sehingga kurang menunjang terciptanya situasi santri yang tertib. Oleh sebab itu, dukungan sarana mutlak diperlukan agar proses belajar mengajar dapat berjalan secara optimal. Itu sebabnya, pemerintah telah menetapkan standar sarana dan prasarana sebagaimana tercantum dalam Standar Nasional Pendidikan tahun 2005.

Madrasah Aliyah Darul Arqam Garut berpeluang sangat besar untuk terus berkembang, berprestasi dan bersaing dengan lembaga pendidikan lainnya di Republik ini, khususnya di Garut dan Jawa Barat. Sarana dan prasarana yang ada pada saat ini dapat dijadikan modal pokok untuk melangkah jauh ke depan apabila eksistensi, visi dan misi MA Darul Arqam serta prestasi yang telah dicapai dapat terus dipelihara bahkan terus ditingkatkan. Kondisi ini memerlukan kehadiran guru yang profesional dengan seperangkat kompetensi yang harus dimilikinya.

Era globalisasi yang ditandai dengan ketatnya persaingan, keterbukaan, dan kebebasan berekspresi begitu marak melanda sebagian generasi muda, 
pelajar dan mahasiswa yang sulit untuk dikendalikan. Globalisasi dapat menimbulkan dampak negatif yang luar biasa bagi perkembangan mental, intelektual dan akhlak generasi muda. Sistem pendidikan yang diselenggarakan oleh Madrasah Aliyah Darul Arqam sangat menarik perhatian para orang tua (calon) murid yang menyadari akan tanggung jawabnya sebagai lembaga pendidik pertama yang mengajarkan akhlak. Terlebih lagi, legalitas dan perhatian pemerintah yang sejalan dengan sistem dan kebijakan Kemendikbud dan Kemenag semakin mantap. Berbagai perguruan tinggi, baik negeri maupun swasta terbuka lebar bagi lulusan Madrasah Aliyah Darul Arqam untuk melanjutkan studinya.

Madrasah Aliyah Darul Arqam sebagai lembaga pendidikan kader Muhammadiyah akan menghadapi beberapa tantangan yang tidak ringan. Madrasah ini harus mampu mempertahankan eksistensi, visi, misi, potensi dan prestasi yang telah dicapai selama ini dengan sunguh-sungguh, terutama yang berkaitan dengan 4C, yaitu: customer, company, currency dan country. Untuk mencapai itu mereka dituntut untuk selalu meningkatkan kualitas para pendidik yang berkarakter basthatan fi al-ilmi wa l-jismi demi keberlangsungan eksistensi Madrasah Aliyah Darul Arqam Garut ke depan. Di samping itu, harus mewaspadai dampak negatif dari proses globalisasi dan demokrasi yang kebablasan, berupa perilaku dan praktek budaya yang sekuler, hedonis, liberalis, kapitalis, materialistis dan bebas nilai yang terkesan membebaskan segala macam cara. Bahkan kita tidak bisa menutup mata dengan semakin canggihnya media cetak dan elektronik yang menampilkan tayangan, gambar atau lukisan yang tidak mendidik, seperti: kekerasan, seks bebas dan mistik. Sementara pada saat yang bersamaan Bangsa Indonesia tengah dihadapkan pada masalah kemiskinan, keterbelakangan, ketidakberdayaan serta kekufuran yang melanda sebagian masyarakat. Dengan demikian, pelaksanaan pendidikan di madrasah Aliyah Darul Arqam Garut ini harus dapat menjawab tantangan zaman sehingga diperlukan kehadiran guru yang kreatif, inovatif, menantang dan menyenangkan dengan dilandasi nilai-nilai Ilahiyah dalam melaksanakan tugas mulianya di negeri ini.

2. Madrasah Aliyah Negeri Cipasung Tasikmalaya

Madrasah Aliyah Negeri Cipasung Tasikmalaya didukung oleh tenaga pendidik yang memadai yang telah memiliki kualifikasi akademik minimal S1 bahkan ada sejumlah guru yang telah memiliki kualifikasi S2. Dengan sendirinya mereka bisa menampilkan sosok guru yang tidak saja dapat mengajar tetapi didukung oleh empat kompetensi guru, yakni kompetensi pedagogik, kepribadian, sosial dan profesional. Hal ini telah memenuhi standar yang telah ditetapkan oleh pemerintah bahkan secara jelas dalam Undang-Undang Guru dan Dosen No. 14 tahun 2005, khususnya pasal 8 dan 9 yang mempersyaratkan bahwa pendidik mempunyai kualifikasi pendidikan minimal S1 atau D4.

Madrasah Aliyah Negeri Cipasung memiliki in put siswa yang baik dengan menggunakan sistem seleksi yang dilakukan oleh pengelola. Mereka yang 
diterima hanya merupakan siswa yang telah memenuhi standar kelulusan (passing grade) yang telah ditetapkan oleh sekolah. Dari segi in put siswa yang masuk, madrasah ini dari tahun ke tahun tidak pernah kekurangan murid. Para orang tua banyak memercayakan pendidikan anaknya di madrasah ini karena di samping mereka bisa sekolah juga mereka dididik dalam lingkungan pesantren Cipasung. Selain lingkungan yang kondusif untuk tempat belajar, madrasah ini memiliki fasilitas yang cukup memadai seperti laboratorium IPA, komputer dan sarana olah raga. Madrasah ini pun memiliki pusat sumber belajar bersama (PSBB) yang digunakan guru-guru yang bergabung dalam koordinasi Kelompok Kerja Madrasah (KKM) MAN Cipasung. Madrasah ini tidak mempunyai otoritas untuk merekrut calon guru. Rekrutmen guru dilakukan langsung oleh Kementerian Agama Pusat yang pola rekrutmennya sulit terbebas dari praktik kolusi korupsi dan nepotisme ( $\mathrm{KKN}$ ) karena kerap kali tidak mencerminkan kebutuhan tenaga guru yang ada. Di samping itu, masih adanya guru yang berstatus guru tidak tetap (GT'T) yang dibayar dari anggaran madrasah yang terbatas sehingga kesejahteraan yang diberikan belum memadai dan kurang layak untuk hidup sebagai seorang guru. Oleh sebab itu, dukungan secara finansial merupakan hal yang penting, agar para guru dapat mengabdi dengan sepenuh hati di Madrasah ini tanpa harus mencari pekerjaan sambilan di luar tugas pokoknya sebagai pendidik. Jabatan guru merupakan jabatan terhormat dengan demikian perlu didukung oleh kesejahteraan yang memadai agar guru dapat melaksanakan tugasnya dengan sepenuh hati. Hal ini sejalan dengan amanat UUGD No 14 tahun 2005, khususnya pasal 14, 15, 16, 17, 18 dan 19.

Kemampuan guru yang memegang bidang studi/mata pelajaran, walaupun mempunyai latar belakang pendidikan yang sesuai dengan mata pelajaran yang diampunya, tetapi kompetensi mereka sebagai guru belum merata dan memadai sepenuhnya, baik yang menyangkut kompetensi pedagogik, kepribadian, sosial maupun profesional. Kedisiplinan guru dalam hal ketepatan waktu ketika masuk kelas masih perlu ditingkatkan sehingga berpengaruh terhadap kedisiplinan siswa ketika masuk kelas. Hal ini terjadi khususnya pada jam pertama masuk kelas.

Madrasah Aliyah Negeri Cipasung Tasikmalaya memiliki rata-rata kemampuan bertaraf nasional bahkan internasional, yang ditunjukkan oleh beberapa guru dan kepala madrasah yang telah mengikuti beberapa kegiatan pengembangan profesi keguruan dan manajemen sekolah di tingkat nasional dan internasional. Sebagai MAN model, Madrasah Aliyah Negeri Cipasung Tasikmalaya berpeluang sangat besar untuk terus berkembang, berprestasi dan bersaing bersama lembaga pendidikan lainnya di Republik ini. Dengan didukung sarana dan prasarana yang ada pada saat ini dapat dijadikan modal pokok untuk melangkah jauh ke depan apabila eksistensi, visi, dan misi MAN Cipasung serta prestasi yang telah dicapai dapat terus dipelihara bahkan terus ditingkatkan. Kondisi ini memerlukan kehadiran guru yang profesional dengan seperangkat kompetensi yang harus dimilikinya. 
Tuntutan masyarakat, khususnya para orang tua semakin tinggi. Terlebih para orang tua yang merasa khawatir akan masa depan putra-putrinya. Kekhawatiran ini disebabkan karena mereka dihadapkan pada masa depan yang penuh persaingan dan serba tidak pasti. Hanya mereka yang mempunyai kemampuan lebih yang dapat melenggang dan mengarungi arus kehidupan yang kian hari kian beragam dan menantang. Di samping perkembangan teknologi komunikasi, informasi dan globalisasi yang semakin pesat. Hal ini ditandai dengan arus demokrasi yang kebablasan, berupa prilaku dan praktek budaya sekuler, hedonis, liberalis, kapitalis, materialistik dan bebas nilai yang terkesan membebaskan segala macam cara. Bahkan kita tidak bisa menutup mata dengan semakin canggihnya media cetak dan elektronik yang menampilkan tayangan, gambar, atau lukisan yang tidak mendidik, seperti: kekerasan, seks, dan mistik. Dengan demikian, guru harus dapat memberikan masukan, penyegaran dan pemulihan yang positif, agar siswanya tidak terjerembab pada pola pikir dan pola hidup duniawi yang bersifat nisbi.

Berdasarkan analisis SWOT, dapat dirumuskan beberapa isu strategis yang dihadapi madrasah berbasis pesantren saat ini yaitu:

a. Peningkatan SDM pendidik cenderung stagnan bahkan masih terjebak dengan kegiatan rutinitas tanpa ada tindakan dan loncatanloncatan yang berarti dalam peningkatan kualitas pendidik sehingga akan berimbas pada hasil belajar siswa;

b. Pola rekrutmen yang ada memaksa para guru terjebak dengan penyakit mental kolusi dan nepotisme sehingga banyak guru yang berusaha untuk lolos seleksi walaupun dilakukan dengan cara-cara yang justru bertentangan dengan nilai-nilai dan semangat keguruan dan keislaman.

c. Tingkat kesejahteraan guru relatif masih rendah, jika dilihat dari gaji dan tunjangan guru serta insentif lainnya sehingga berpengaruh pada konsentrasi guru dalam melaksanakan tugas dan tanggung jawab sebagai pendidik dan pencerah bagi generasi mendatang.

d. Minimnya sarana dan prasarana serta alokasi anggaran bagi pembangunan infrastruktur madrasah.

e. Kurangnya perbedaan nilai tambah madrasah sebagai institusi pendidikan Islam dengan kekhasan ciri Islam jika dibandingkan dengan satuan pendidikan umum.

f. Citra madrasah sebagai pendidikan kelas dua (second class) masih melekat kuat di masyarakat sehingga cukup berpengaruh terhadap kualitas in put yang berminat melanjutkan sekolah ke madrasah.

Walaupun Madrasah Aliyah Darul Arqam Muhammadiyah Garut dan Madrasah Aliyah Negeri Cipasung Tasikmalaya dari tahun ke tahunnya telah mengalami peningkatan kualitas lulusan, namun kedua madrasah ini belum menerapkan manajemen pembinaan kompetensi guru yang menyeluruh dan 
terpadu, dan belum melakukan lompatan mutu yang signifikan bahkan cenderung masih terjebak dalam rutinitas saja. Manajemen pembinaanya belum menyentuh pada aspek yang secara substantif dapat mendorong guru terus berfikir kritis dan mengembangkan pola pikir kelas tinggi. Padahal berfikir kelas tinggi (bigher-order thinking skills) penting dikuasai agar guru dapat melakukan analisa, problem solving dan berfikir kritis (critical thinking). Kedua madrasah berbasis pesantren ini masih menggunakan pola rekrutmen yang sering kali menyebabkan guru terjebak dalam praktik suap, kolusi dan nepotisme. Beberapa calon guru berusaha agar mereka lolos seleksi walaupun dengan menempuh caracara yang justru bertentangan nilai-nilai dan semangat keguruan atau keislaman. Walaupun demikian, pola pembinaan kompetensi guru pada dua madrasah berbasis pesantren ini sudah menerapkan fungsi-fungsi manajemen seperti dimulai dengan tahap perencanaan, pengorganisasian, pelaksanaan kemudian diakhiri dengan evaluasi. Perencanaan, pengorganisasian, pelaksanaan dan evaluasi didasari oleh visi, misi dan tujuan yang telah ditetapkan dengan memperhatikan hasil analisis internal dan eksternal madrasah serta mempertimbangkan kepentingan seluruh warga sekolah yang terlibat (stakeholders) ditunjang dengan dukungan kelengkapan sarana dan prasarana pendidikan yang ada.

Dengan mempertimbangkan hal di atas, maka pembinaan perlu dilakukan sejak rekrutmen calon guru. Ini berarti bahwa guru yang direkrut adalah guru yang mempunyai kemampuan yang dapat berfikir kritis (critical thinking) sehingga dapat menyelesaikan setiap problema yang dihadapi ketika ia melaksanakan tugasnya dan pola pembinaan guru mestinya mempertimbangkan nilai-nilai religius (jujur, adil, profesional dan terbuka) sebagai ciri dari madrasah yang berbasis pesantren. Pada madrasah aliyah berbasis pesantren ini pembinaan kompetensi guru didasarkan pada sunah Rasulullah SAW dan tradisi para al-salaf as-shâlih dalam membina umat di zamannya. Dalam pelaksanaan pembinaanya diketahui bahwa 'sunnah' dan tradisi para salaf as salib itu didasarkan pada pesan Ilâhiyyah sebagaimana yang tercantum dalam Kitâbullâh, yakni: lillâh, uswatun hasanah, bil-hikmah, mavidzah hasanah dan mujâdalah.

\section{Konsep Alternatif Strategi Pembinaan Kompetensi Guru Madrasah Berbasis Pesantren}

Darling \& Hamond (1999: 136) mengatakan bahwa desain pengembangan profesionalisme guru menuntut para guru merancang apa dan bagaimana seharusnya siswa belajar disertai dengan keyakinan bahwa semua siswa dapat mencapai standar akademik yang lebih tinggi. Sanusi (2007: 14) mengatakan bahwa secara normatif proses belajar mestinya dilandasi dengan nilai-nilai religius sebagai a system of mega values (sistem nilai Ilahiyah). Nilai-nilai tersebut adalah: a) Minallah, bersumber dari Allah; b) Billâh, bekerja dengan kekuatan Allah; c) Ma'allâh, dalam proses selalu bersama dengan Allah; d) Lillâh, dipersembahkan untuk Allah; e) Illallahh, kembali kepada Allah. Morris 
sebagaimana dikutip oleh Makmun (2009: 393) mengungkapkan bahwa pendidik (educator) dan khususnya guru (teacher) harus memahami landasan filosofis, teoretis, sosiologis, antropologis dan psikologis serta sistem nilai (value system) di samping menguasai secara maksimal metodologi serta dapat menggunakan teknologi yang relevan dengan pelaksanaan pendidikan. Guru mestinya juga memiliki jiwa dan semangat keterpanggilan (calling) atas tugas yang diembannya.

Manajemen pembinaaan kompetensi guru hendaknya diawali dari pola rekrutmen yang objektif, transparan dan akuntabel sehingga dapat merekrut guru yang kompeten, baik dari segi pedagogik, kepribadian, sosial maupun profesional seperti yang diamanatkan dalam Undang-Undang Guru dan Dosen No. 14 tahun 2005. Dengan pola rekrutmen seperti ini, guru akan dapat terhindar dari praktik "KKN". Pola rekrutmen yang objektif, transfaran dan akuntabel memperhatikan hal-hal seperti: a) pelaksanaan rekrutmen melibatkan pihak ketiga yang independen; b) materi tes harus mencerminkan kompetensi guru sesuai dengan bidang studi yang diperlukan yang meliputi kompetensi pedagogik, kepribadian, sosial dan profesional; c) memprioritaskan lulusan lembaga penghasil tenaga guru (LPTK) dan keguruan yang berkualitas/mempunyai grade tinggi; d) seluruh stakeholder madrasah berfungsi sebagai pemantau sehingga akurasi hasil tes dapat dipertanggungjawabkan.

Manajemen pembinaan kompetensi guru perlu mengoptimalkan fungsi manajemen, yakni dari mulai perencanaan, pengorganisasian, pelaksanaan dan evaluasi. Dari tahap perencanaan, pengorganisasian, pelaksanaan dan evaluasi didasari oleh visi, misi dan tujuan yang telah ditetapkan dengan menghubungkan pada hasil analisis internal dan eksternal madrasah serta mempertimbangkan kepentingan seluruh warga sekolah yang terlibat (stakeholders) ditunjang dengan dukungan kelengkapan sarana dan prasarana pendidikan. Pembinaan terhadap guru di madrasah berbasis pesantren juga perlu dilakukan dengan mempertimbangkan pesan-pesan Ilâhiyyah yang bersandar pada Kitâbullâh dan Sunah Rasulullah SAW, sehingga pembinaan dilakukan tidak lepas dari landasan nilai-nilai dan spirit agama Islam. Sunnah dan tradisi para al-salaf as-shâlih itu berdasarkan pada pesan Ilâhiyyah sebagaimana yang tercantum dalam Kitabullâh, yakni: lillahh, uswatun hasanah, bil-bikmah, mauidzah hasanah dan mujâdalah.

Konsep pembinaan guru di madrasah yang berbasis pesantren mestinya mengedepankan nilai-nilai kepesantrenan sehingga tercipta hubungan yang harmonis antara pengawas, kepala madrasah dan pimpinan pesantren sebagai pembina terhadap guru sebagai binaannya. Manajemen pembinaan guru madrasah berbasis pesantren harus dimulai dari pola rekrutmen yang baik kemudian dilakukan proses pembinaan kompetensinya dengan mengoptimalkan tiga fungsi manajemen, yakni perencanaan, pelaksanaan dan evaluasi. Dalam implementasinya perlu mempertimbangkan beberapa hal, yakni: 1) visi, misi dan tujuan madrasah; 2) analisis stakeholders; 3) analisis internal madrasah; 4) analisis eksternal; 5) struktur dan fasilitas pendukung; 6) nilai-nilai religious terdiri dari: lillâh, uswatun hasanah, bil-bikmah, mauidzah hasanah dan mujâdalah. 


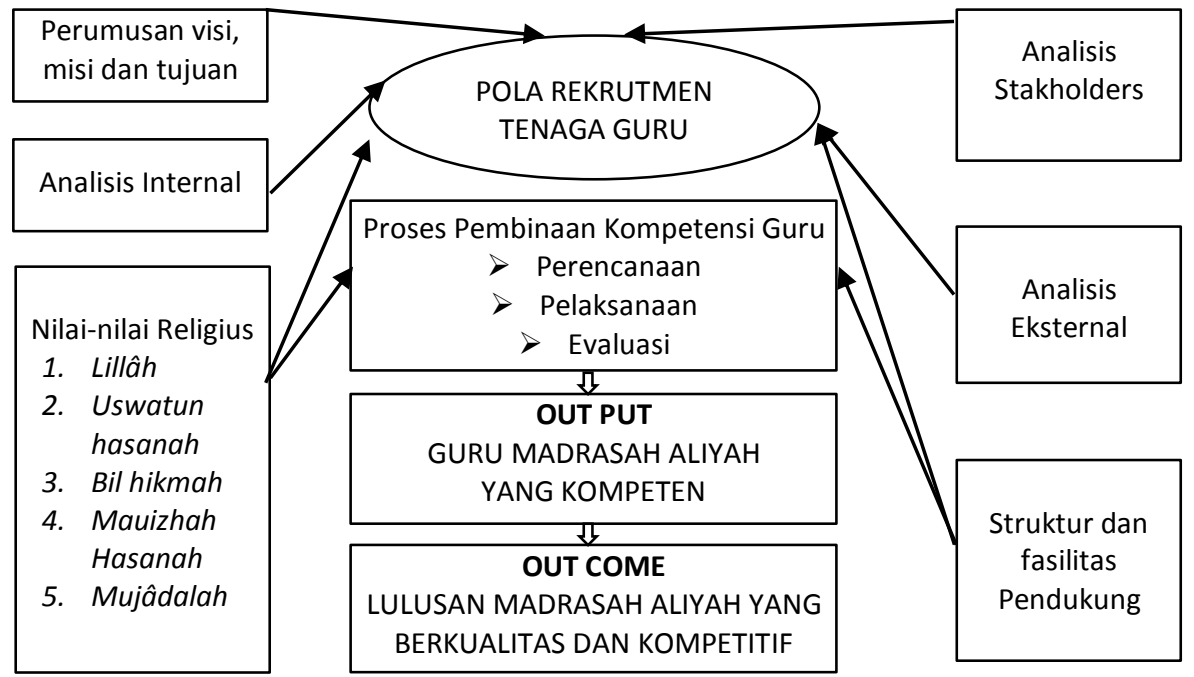

Perencanaan yang dimaksud dalam pembinaan kompetensi guru hendaknya didasarkan pada tiga hal yaitu: tujuan, strategi dan program. Tujuan pembinaan kompetensi guru adalah agar dapat melahirkan guru yang bermutu dengan ditunjang empat kompetensi, yakni kompetensi pedagogik, kepribadian, sosial dan profesional. Tujuan ini harus diawali dengan strategi awal yang baik yakni dengan pola rekrutmen guru yang objektif, transparan dan akuntabel dengan memprioritaskan lulusan perguruan tinggi keguruan yang mempunyai grade baik. Setelah itu, dirumuskan program-program pembinaan yang perlu dilakukan oleh kepala madrasah, pengawas bahkan pimpinan pesantren untuk melakukan pembinaan di dalam sekolah secara berkesinambungan. Rumusan programnya dibuat dalam rangka meningkatkan kualifikasi dan kompetensi guru seperti yang diamanatkan dalam Undang-Undang Guru dan Dosen No. 14 Tahun 2005, yakni minimal pendidikan S1 atau D4 dengan didukung empat kompetensi, yakni kompetensi pedagogik, kepribadian, sosial dan profesional. Tahap berikutnya adalah pelaksanaan pembinaan dengan bersandar pada pelaksanaan pembinaan guru yang sesuai dengan spirit dan nilai-nilai religius. Program pembinaannya dalam bentuk peningkatan kualitas akademik, program sertifikasi, supervisi, dan pelatihan yang terintegrasi. Akhirnya seluruh kegiatan pembinaan di akhiri dengan evaluasi agar terlihat keberhasilan atau kegagalannya. Hasil evaluasi ini dijadikan dasar untuk merumuskan langkah tindak lanjut demi berlangsungnya perbaikan yang berkesinambungan. Suksesnya program pembinaan kompetensi guru perlu ada political will dari pemerintah dan dukungan dari seluruh lapisan masyarakat sehingga tenaga guru yang direkrut merupakan putra putri terbaik bangsa bukan sumber daya manusia sisa setelah yang bersangkutan tidak diterima kerja di mana-mana. Grade perguruan tinggi dari penyelenggara pendidikan keguruan pun menjadi pertimbangan utama dalam menyeleksi calon guru. Cirinya; 1) lembaga pendidikan guru dilengkapi dengan 
fasilitas praktik yakni adanya sekolah/madrasah laboratorium sebagai tempat latihan/magang bagi mahasiswa calon guru sehingga mereka dapat mematangkan kemampuan keguruannya; 2) seluruh calon guru diasramakan (boarding school), sehingga dalam kehidupan berasrama itu terbina karakter pribadi dan sikap profesionalnya; 3) membangun e-learning dan e-book systems accompanied by regional /local universities/schools collaborate tutoriail system. Guru yang baik juga harus didukung oleh finansial yang cukup, baik untuk pengadaan fasilitas maupun untuk meningkatkan kesejahteraan guru. Kesejahteraan guru yang terjamin dapat menyebabkan guru lebih fokus dalam melaksanakan tugasnya, sehingga tidak harus mencari pekerjaan sampingan demi menutupi keperluan hidup diri dan keluarganya (Makmun, 2009: 398).

Dalam rangka mengimplementasikan konsep alternatif dan strategi pembinaan kompetensi guru yang baik diperlukan syarat-syarat: a) adanya kebijakan yang kuat dan mengikat dari pemerintah dengan didukung oleh seluruh lapisan masyarakat; b) adanya pola rekrutmen calon guru yang mengedepankan prinsip objektif, transfaran dan akuntabel sehingga guru yang terekrut benar-benar mempunyai kompetensi seperti yang telah diamanatkan dalam Undang-Undang Guru dan Dosen No. 14 Tahun 2005; c) adanya pola pembinaan kompetensi guru yang terencana, terprogram, terpadu dan berkelanjutan sesuai dengan asas-asas dan fungsi manajemen modern, baik dalam perencanaan, pelaksanaan maupun evaluasinya. Dalam konteks pelaksanaan pembinaan kompetensi guru di madrasah berbasis pesantren sunah Rasulullah SAW dan tradisi para salafussalih patut dijadikan nilai dasar pembinaan yang didasarkan pada pesan Ilâhiyyah sebagaimana yang tercantum dalam Kitâbullâh, yakni: lillâh, uswatun hasanah, bil-hikemah, mauidzah hasanah dan mujâdalah.

\section{SIMPULAN}

Kualifikasi akademik guru pada Madrasah Aliyah Darul Arqam Muhammadiyah Garut dan Madrasah Aliyah Negeri Cipasung yang berbasis pesantren ini telah memenuhi kualifikasi pendidikan minimal seperti yang diamanatkan dalam Undang-Undang Guru dan Dosen No. 14 Tahun 2005. Kedua madrasah tersebut telah melakukan pembinaan kompetensi gurunya dengan mengimplementasikan asas dan fungsi-fungsi manajemen modern, mulai dari perencanaan, pengorganisasian, pelaksanaan hingga evaluasi. Namun demikian, kedua madrasah ini belum melakukan manajemen pembinaan kompetensi guru yang menyeluruh dan terpadu, bahkan cenderung masih terjebak dalam rutinitas saja. Manajemen pembinaanya belum menyentuh pada hal-hal yang bersifat substantif yang mendorong guru terus-menerus berfikir kritis dan mengembangkan pola pikir kelas tinggi (higher-order thinking skills) sehingga diharapkan guru dapat mengatasi dan mengantisipasi tantangan zaman, berselancar dalam kekalutan (surving on chaos) dan siap menghadapi kompleksitas kehidupan yang semakin menantang. Problematika dalam pembinaan kompetensi guru pada MA Darul Arqam dan MAN Cipasung ditandai dengan 
adanya kekuatan, kelemahan, peluang dan tantangan yang memiliki karakteristik tersendiri sehingga masih diperlukan strategi alternatif demi meningkatkan kompetensi para gurunya.

\section{DAFTAR PUSTAKA}

Batak Post Online, edisi Senin 23/3/11. dalam http://batakposonline.com/content/view/5677/60/diunduh 09/08/11.

Clutterbuck, D. 1999. The Power of Empowerment. London: Kogan Page.

Darling-Hamond, L. 2006. Powerful Teacher Education: Lesson from Exemplary Program. U.S.: Jossey-Bass.

Darling \& Hamond, L. 1999. Powerful Teacher Education: Lesson from Exemplary Program. U.S.: Jossey-Bass.

Departemen Agama RI.1989. Al-Qur'an dan Terjemahnya. Semarang: Toha Putra.

Depdiknas. 2008. Pedoman Penyelenggaraan Program Sertifikasi Guru Dalam Jabatan Melalui Jalur Pendidikan. Jakarta: Depdiknas.

Hadiyanto. 2004. Mencari sosok Desentralisasi Manajemen Pendidikan di Indonesia. Jakarta: Rineka Cipta.

http://mapenda-garut.blogspot.com/2012/07/bantuan-peningkatan-kualifikasi program.html diunduh tanggal 18/07/2012.

http://www.kompas.com diunduh tanggal 29/01/11

Killen, R. 1998. Effective Teaching Strategies: Lesson from Research and Practice (Second Edition). Australia: Social Science Press.

Miles, M.B. dan Huberman, A.M. 1992. Qualitative Data Analysis; A Source Book of New Methods. California: SAGE Publication.

Mulyasa, E. 2007b. Standar Kompetensi dan Sertifikasi Guru. Bandung: Rosda.

Mulyasa, E.2007a. Manajemen Berbasis Sekolah; Konsep, Strategi, dan Implementasi.

Cet. XI. Bandung: Rosdakarya.

Peraturan Menteri Pendidikan Nasional Nomor 16 tahun 2007.

Spencer, L.M \& Spencer, S.M. 1993. Competence At Work: Model For Superior performance. New York: John Wiley \& Sons.

Suparno, P. 2008. Filsafat Konstruktivisme Dalam Pendidikan. Yogyakarta: Kanisius.

Terry, R.G. 1977. Principle of Management. Homewood Illionis : Richard D. Irwin Inc.

Undang-Undang Guru dan Dosen No 14 Tahun 2005. 